\title{
PUTTING POLITICS TO THE COMMON PEOPLE - SPECIAL FEATURES IN HO CHI MINH'S VIEWPOINT ON THE WORK OF COMMUNITY POLICING
}

\author{
Vu Hoang Toan \\ The People's University of Police
}

\begin{abstract}
"Putting politics in community policing" is one of Ho Chi Minh's views on the community policing arts. In the past, "Putting politics in community policing" was tested by Ho Chi Minh's revolutionary activities and our Party to be righteous, it cemented the relationship between the Party and the people and contributing to the great victories of Vietnamese people. This article is based on dialectical materialism methodology. The specific research methods of this include an analysis-synthesis method, a logical - historical method, a comparative method to present scientific arguments about Ho Chi Minh's point of view. The Communist Party of Vietnam can apply this view to improve the efficiency of community policing in the future, such as raising awareness of cadres and party members about the importance and the role of community policing; incessantly fostering to raise the qualifications of cadres and party members in the community policing according to Ho Chi Minh's point of "Putting politics in community policing"; grasping thorough out the viewpoint of "Putting politics in community policing" by upholding the methods of setting an example and commendation along with raising disciplines for cadres and party members in the community policing.
\end{abstract}

Key words: Politics; The work of community policing; The common people; The Communist Party of Vietnam; Ho Chi Minh.

Received: 15/01/2020; Revised: 11/02/2020; Published: 21/02/2020

\section{ĐƯA CHÍNH TRI VÀO GIŨ๋A DÂN GIAN - NÉT ĐĀC SĂC TRONG QUAN ĐIỂM CỦA HỒ CHÍ MINH VỀ CÔNG TÁC DÂN VẬN}

\author{
Vũ Hoàng Toàn \\ Truờng Đại học Cảnh sát nhân dân
}

TÓM TẮT

"Đưa chính trị vào giữa dân gian” là một trong những quan điểm về nghệ thuật dân vận của Hồ Chí Minh. Trong quá khứ, “đưa chính trị vào giữa dân gian” đã được thực tiễn hoạt động cách mạng của Hồ Chí Minh và Đảng ta kiểm nghiệm là đúng đắn, đem lại sự gắn bó máu thịt giữa Đảng với nhân dân, góp phần làm nên những thắng lợi vĩ đại của dân tộc Việt Nam. Bài viết dựa trên cơ sở phương pháp luận duy vật biện chứng, các phương pháp nghiên cứu cụ thể gồm phương pháp phân tích - tông hợp, phương pháp lôgíc - lịch sử, phương pháp so sánh để đưa ra các luận điểm khoa học về quan điểm trên của Hồ Chí Minh. Đảng Cộng sản Việt Nam có thể áp dụng để nâng cao hiệu quả công tác dân vận trong thời gian tới. Cụ thể, không ngừng nâng cao nhận thức của đội ngũ cán bộ, đảng viên về tầm quan trọng, vai trò của công tác dân vận; bồi dưỡng nâng cao trình độ của đội ngũ cán bộ, đảng viên trong công tác dân vận theo quan điểm "đưa chính trị vào giữa dân gian"; quán triệt quan điểm “đưa chính trị vào giữa dân gian” bằng việc nêu cao phương pháp nêu gương, khen thưởng đi đôi với nêu cao kỷ luật, kỷ cương đối với cán bộ, đảng viên trong công tác dân vận.

Từ khóa: Chính trị; Công tác dân vận; Dân gian; Đảng Cộng sản Việt Nam; Hồ Chí Minh.

Ngày nhận bài: 15/01/2020; Ngày hoàn thiện: 11/02/2020; Ngày đăng: 21/02/2020

Email:vuhoangtoandhcs@gmail.com

DOI: https://doi.org/10.34238/tnu-jst.2020.03.2549 


\section{Introduction}

Ho Chi Minh always emphasized that community policing is one of the important aspects of the Communist Party of Vietnam and of each cadre and party member. In the life and revolutionary career of $\mathrm{Ho}$ Chi Minh, the practice of community policing has been thoroughly grasped to the point that it becomes an art and a "clever" skill of Ho Chi Minh. In particular, one of the contents of Ho Chi Minh's community policing arts is "putting politics into community policing" in order to make the Party's guidelines and policies, the Country's policies and laws be easier to understand and become motivation of people. Therefore, people can believe and follow to the leadership of the Party, successfully implement the revolutionary goals. The study and thorough understanding of this viewpoint will take part in raising the quality of the Party's campaign in the coming time.

2. Viewpoint of "putting politics in community policing" in Ho Chi Minh's work

Collated by "Ho Chi Minh series: The whole series" published by National Political Publishing House - Truth in 2011, the phrase "bringing politics in community policing" was first mentioned in Change the way we work. He wrote, "We have to put politics in community policing". Previously, everything was always "commanded". From now on, everything relies on "people's needs". "Thus, the policy, officials and people will agree, that our Party will develop quickly and steadily" [1, p. 286]. Although the survey of speeches and articles Ho Chi Minh's political life showed that he almost presented this viewpoint once, however, in his political activities (especially in the process of carrying out the community policing), it is always thoroughly grasped. Specifically, it is expressed in the following basic contents:
Firstly, "putting politics in community policing" is one of Ho Chi Minh's opinions about community policing arts.

President Ho Chi Minh is the best example of the artistic movement. In the first decade of the twentieth century, when our country was obstructing the way of saving the country, Ho Chi Minh was the one who found the right way for Vietnamese people. The thing making Ho Chi Minh's policy stand out is bringing his policy about the proletariat revolution, which is the nation's new way of saving the country, come to the majority of Vietnamese people. How can more than $90 \%$ of the illiterate population in Vietnam know the proletarian revolution? How to lead the people to persist in their goals and strive to gain independence for the nation, prosperity and happiness for the people? The revolutionary achievements are largely thanks to his artistic movement.

It can be said that one of the important contents about Ho Chi Minh's artistic movement is "Putting politics in community policing". It can be understood that the content of this viewpoint, first of all, is a way to persuade people to contribute ideas and implement the Party's guidelines and policies, laws of the Country, but impose them on the people. He always conceives of how the people believed and followed the Party's leadership and considers it is the difference between the proletariat and the exploiting classes (As the government belongs to the hands of the landlords, feudal and bourgeoisie). This is clearly shown in Ho Chi Minh's concept that, "[...] when facing each situation, we do not know how to explain for the people to understand. So, the things that are directly helpful the people, such as building dikes, protecting dikes, increasing production, popularizing education, etc., officials only giving commands. Therefore, nobody understands, then they are resentful. 
So, No surprise! A very trivial and understandable example is, cakes are a delicious thing, but bringing cakes to make people eat, unwilling put into people's mouths, nobody likes it!" [1, p. 286]. Therefore, even if the policies, guidelines, policies and laws of the Party and the Country are right, but cadres who do not have the art of community policing and are not "delicate", they cannot achieve their goals and even create resentment. In order to fully and effectively deploy the views and policies of the Party, the Country, officials and party members must have the art of community policing and methods to persuade the people. One of the leading methods is to know "Putting politics in community policing".

Secondly, "Putting politics in community policing" by flexible and creative methods which are suitable with the people.

In order to carry out the art of mobilizing people, by using many flexible and creative ways, Ho Chi Minh conveyed revolutionary contents and methods to each citizen. The method of "bringing politics in community policing" is a general method, the art of applying flexible and creative methods and methods is suitable with the masses to pursue people believe in revolutionary movement which has been set up for the benefit of the nation and the people.

Throughout his revolutionary life and career, Ho Chi Minh was an exemplary model for exploring ways to manipulate "bringing politics in community policing" to serve Vietnamese and the world's revolutionary cause. In Ho Chi Minh's works, speeches and articles, we know that he has used flexibly different ways and methods of concertizing the concept "Putting politics in community policing", such as short stories, memoirs, political essays, skits, plays, poems, letters, appeals, posters, cartoons, slogans, leaflets, books, newspapers and radio broadcast, etc.
In terms of content, "bringing politics in community policing" presenting theoretical contents, ways, revolutionary methods through understandable things to the masses. For example, Ho Chi Minh compares the image of the enemy of the Vietnamese nation, as known as capitalism, through the image of a two-sucker leech which one of its suckers "clings to", exploits the proletarians in its own country, and another "cling to", exploits the proletarians in colonial countries. Through this comparison, the requirement of combining the proletariat revolution in the main countries with the colonial countries is a basic way to destroy that enemy; Ho Chi Minh interpreted the socialism for the people with images such as building socialism is the same as farming. People have to work hard with bare feet and muddy hands, and image that fields is a battle, a plow is a weapon, a farmer is a soldier, etc.

Thirdly, "Putting politics in community policing" is not follow the masses blindly.

Ho Chi Minh mentioned that "Putting politics in community policing", respect and loyal to the people should not be understood in the sense of "follow the masses blindly" or populism. At this point, Ho Chi Minh emphasizes his viewpoint and instructs our officials and party members, "We absolutely should not follow the masses blindly" [1, p. 338]. In other words, "Putting politics in community policing" is the opposite of "following the masses blindly".

In Change the way we work, Ho Chi Minh explained the concept of "Putting politics in community policing" in a clear and specific way. According to him, "Putting politics in community policing" means to emphasize the orientation, persuades the people and leads the people to follow the right revolutionary path. However, the content, the method of implementing the revolutionary way cannot be the subjective will of the Party, the 
Country or officials and party members. Ho Chi Minh outlined the way of "bringing politics in community policing" is implemented by cleverly focusing on public opinions and making their opinions a way to lead the masses. He acknowledged that there is people of different strata with different levels of awareness, thus, cadres and party members performing the campaign must understand the characteristics of the masses, their works must rely on the survey and compare ideas, opinion of the masses, take opinions and legitimate aspirations of the masses to lead them by the revolutionary goals set. When people trust and understand the Party's guidelines and policies, the Country's policies and laws which enacted to serve the people, they voluntarily and enthusiastically implement them and achieve great results for the cause of protecting the country and building socialism in Vietnam. That is a way to respect the people, close to the people but absolutely does not blindly follow the masses.

\section{Applying "political putting into between people" by president Ho Chi Minh into the community policing of Vietnamese communist party}

The Communist Party of Vietnam highly emphasizes the importance of the community policing and considers this as a basic aspect of work and a strategic task of the Party. The well-organized community policing has contributed to great victories for Vietnamese revolutionary cause. Because the results of the community policing show how close the relationship between the Party and the masses are and how the revolutionary force led by the Party is the masses has become a unity, etc., they directly affect revolutionary victories. Ho Chi Minh once emphasized, "The people movement is very important. The bad one leads to bad results. Good community policing gains tons of succeeds" [2, p. 234].
Therefore, in recent years, our Party has set out guidelines to increasingly improve the quality of community policing as the Resolution of the 7th Plenum of the Central Executive Committee of the 11th Session on June $3^{\text {rd }}, 2013$ on "strengthening and renewing the party's leadership on the community policing of affairs in the new situation", the contents of leading community policing in the Resolution of the 12th National Party Congress, emulation movement "Smart community policing", etc. In particular, the Party emphasizes that learning and following President Ho Chi Minh's example in community policing is a must. In order to further promote the achieved results, in the coming time, it is possible to thoroughly grasp the view of "bringing politics in community policing" in President Ho Chi Minh's community policing. The Communist Party of Vietnam follows some basic directions:

Firstly, constantly raising the awareness of cadres and party members about the importance and role of community policing in Ho Chi Minh's point of view.

Raising awareness of cadres and party members about the importance and role of community policing in $\mathrm{Ho} \mathrm{Chi}$ Minh's viewpoint is the initial basis for raising the responsible roles of cadres and party members in community policing, then integrates to convey the content of community policing in different ways.

In order to fully grasp this view for cadres and party members, first of all, they must raise their awareness about the importance and the role of mobilizing people for the Vietnamese revolutionary cause. Specifically, keeping on doing well and further improving the effectiveness of propaganda, education, awareness raising, sense of responsibility of all cadres and party members about the community policing, making each recipient 
deeply aware of the role of the masses in the Vietnamese revolutionary cause, the revolution is the cause of the people, by the people and for the people; awareness of the community policing is the basis and foundation of the close relationship between the Party and the people; it is a strategic work to bring the Party's forces and strength in effectively fulfilling all undertakings; community policing is all cadres and party members' duty; we must respect the people, the people, close to the people, have a strong relationship with the people, constantly promoting the people's mastery, etc.

Secondly, constantly fostering and improving the qualifications of cadres and party members in the campaigning of $\mathrm{Ho}$ Chi Minh's view "bringing politics in community policing".

Thoroughly grasping Ho Chi Minh's "Putting politics in community policing" view for cadres and party members must not only be theories and words, but also must be closely associated with practical work. In fact, Ho Chi Minh did not say much about "Putting politics in community policing" (As surveyed through the Ho Chi Minh series published by the National Political Publishing House Truth released in 2011, Ho Chi Minh only wrote this phrase once) but it was implemented during his revolutionary activities. Therefore, thoroughly grasping Ho Chi Minh's "Putting politics in community policing" view for cadres and party members may be implemented by many different methods but its practical effectiveness must be attached with results and takes practice as a standard of awareness and action development of officials and party members.

From the above perspective, it is possible to use a variety of methods such as using the media, thematic training sessions, exchanging experiences of cadres who are effective in mobilizing people, movements "smart people" at all levels, branches, etc.

Thirdly, fully grasping the viewpoint of "bringing politics in community policing" by upholding the methods of setting an example and commendation along with raising the discipline towards cadres and party members in the work of mobilizing people.

Studying and mastering the concept of "bringing politics in community policing" through the example-setting method, first of all, Ho Chi Minh is the good example in the process of implementing community policing. The Party Committees at all levels can closely grasp the above viewpoint with the process of implementing the "Study and follow Ho Chi Minh ideology, morality and style" campaign; make cadres, party members in general and officials in charge of public affairs in particular learn how to say, write, thoroughly think and act as Ho Chi Minh to "bring politics in community policing". Ho Chi Minh is not the only good example, it is necessary to know how to promote the good one in carrying out the community policing work at all levels, branches, all cadres and party members in every position. In particular, the responsibilities of the leaders and commanders of agencies and units must be upheld. The head must show a high sense of responsibility, regularly cultivate ethical qualities and lifestyles, has an exemplary style, and volunteering to successfully implement the guidelines and policies of the Party and the Government, books and laws of the Country by using Ho Chi Minh's policies, which include "putting politics in community policing", etc.

In parallel with the good example, the Party committees should focus on promoting the role of inspection, supervision, and discipline in implementing the community policing of cadres and party members. In case that the elements of the economy market still exist in 
our country, negative signs still exist in numerous cadres and party members (showed in Central Resolution 4 (Session XI) on current urgent issues on Party building and Central Resolution 4 (term XII) on building and regulating the Party, contributing to the struggle, preventing, and reversing the decline in political and moral ideology, lifestyle, internal manifestations of "self-evolution", "self-transformation"). Therefore, promoting and practicing the method of "bringing politics in community policing" is also closely associated with the fight against negative manifestations in cadres and party members, which causes significant impacts on the quality of implementing community policing of Party, the strong relationship between the Party and the people.

\section{Conclusions}

"Putting politics in community policing" is one of Ho Chi Minh's views on movement arts, which is implemented by flexible, creative and suitable methods for people; grasping thoroughly the ideology of the people, close to the people, promote the strength and ownership of the people and completely opposite the meaning of blindly following the masses. With the results achieved through Ho Chi Minh's implementation of this viewpoint, the Communist Party of Vietnam can apply it to improve the efficiency of community policing in the coming time, in particular, constantly raising awareness of cadres and party members about the importance and role of community policing in $\mathrm{Ho}$ Chi Minh's viewpoint; incessantly fostering to raise the qualifications of cadres and party members in the campaign of community policing according to Ho Chi Minh's point of "putting politics in community policing"; thoroughly grasping this viewpoint by upholding the method of setting an example and commendation in parallel with upholding discipline towards officials and party members in the work of community policing.

\section{REFERENCES}

[1].Ho Chi Minh' Complete works (in Vietnamese), vol. 5, Ha Noi: The National Political Publishing House, 2011.

[2]. Ho Chi Minh' Complete works (in Vietnamese), vol. 6, Ha Noi: The National Political Publishing House, 2011. 